\title{
Association between maternal breastfeeding and the development of non-nutritive sucking habits
}

\author{
Relação entre aleitamento materno e o desenvolvimento de hábito de sucção não nutritiva
}

Gabriela Lopes Mesquita FREIRE ${ }^{1}$

Junia Carolina Linhares FERRARI²

Célio PERCINOTO

\section{ABSTRACT}

\section{Objective}

To analyze the association of maternal breastfeeding time with the introduction of non-nutritive sucking habits in children attending the Baby Clinic at the Araçatuba College of Dentistry, Universidade Estadual Paulista Júlio de Mesquita.

\section{Methods}

Interviews were conducted with the parents/legal guardians of 228 children, with the aim of obtaining information about the period of natural breastfeeding, the presence of non-nutritive sucking habits and the duration of the habit. A descriptive analysis of the results was performed.

\section{Results}

It was found that $42.5 \%$ of mothers nursed their children up to 6 months, and exclusive maternal breastfeeding was observed in just $13 \%$ of the sample. Amongst the children who were naturally breastfed for a period of more than 6 months, only $32.8 \%$ had non-nutritive sucking habits while 67.2\% did not.

\section{Conclusion}

There was an association between the length of natural breastfeeding and acquiring non-nutritive sucking habits. The habit of sucking on a pacifier was extremely prevalent in babies that only received maternal breastfeeding in the first six months of life. All of the children that were breastfed for only six months made use of a feeding bottle to complement their diet, showing that feeding bottles are still frequently used.

Indexing terms: Breast feeding. Habits. Malocclusion. Oral health. Pacifier.

\section{RESUMO}

\section{Objetivo}

Analisar a associação do tempo de aleitamento materno na instalação de hábitos de sucção não nutritiva em crianças atendidas na Bebê Clínica da Faculdade de Odontologia de Araçatuba da Universidade Estadual Paulista Júlio de Mesquita Filho.

\section{Métodos}

Foram realizadas entrevistas com os pais/responsáveis de 228 crianças, com o objetivo de obter informações sobre o período da amamentação natural, presença de hábito de sucção não nutritiva e duração do hábito. A análise dos resultados foi realizada de maneira descritiva.

\section{Resultados}

Verificou-se que $42,5 \%$ das mães amamentaram seus filhos até os 6 meses, sendo que o aleitamento materno exclusivo foi observado em apenas $13 \%$ da amostra. Dentre as crianças que receberam amamentação natural por período superior a 6 meses, apenas 32,8\% tiveram hábito de sucção não nutritiva e 67,2\% não apresentaram esse hábito.

\section{Conclusão}

Houve associação entre o tempo de aleitamento natural e a aquisição de hábitos de sucção não nutritiva. Observou-se alta prevalência de hábito de sucção de chupeta nos bebês que tiveram o aleitamento materno apenas nos seis primeiros meses de vida. Todas as crianças que tiveram aleitamento materno até os seis meses de idade fizeram o uso de mamadeira como complementação alimentar, mostrando que ainda há grande frequência do uso de mamadeira.

Termos de indexação: Aleitamento materno. Hábitos. Má oclusão. Saúde bucal. Chupeta.

\footnotetext{
${ }^{1}$ Universidad de Barcelona. Gran Via de les Corts Catalanes, 585, 08007, Barcelona, Espanha. Correspondência para / Correspondence to: GLM FREIRE. E-mail: <gabimlopes@gmail.com>.

${ }^{2}$ Universidade Paulista, Campus Brasília. Brasília, DF, Brasil

${ }^{3}$ Universidade Estadual Paulista Júlio de Mesquita Filho, Faculdade de Odontologia, Departamento de Odontologia Infantil e Social. Araçatuba, SP, Brasil.
} 


\section{INTRODUCTION}

Natural breastfeeding satisfies all of a baby's needs during its first few months of life and mother's milk is deemed to be the best food, from a nutritional and immunological point of view, important for promoting the full growth and development of the child ${ }^{1-4}$.

The benefits afforded by maternal breastfeeding have been well established in the literature and include the increased number of antibodies acquired, adequate weight gain for the baby and the correct development of the oral structures involved in the action of sucking ${ }^{1,4-5}$. There is consensus among health professionals that natural breastfeeding also has psychological advantages since it forms an important bond of affection between mother and baby. The duration of each feeding and the period of sucking are important factors and should be considered in terms of the prevention of frustrations and infant anxiety ${ }^{2,6-9}$

From the day they are born, babies have a neural need to suck, satisfying this need at the mother's breast. Sucking is an innate reflex that is natural and important for the baby's survival and is considered to be the earliest behavior pattern exhibited by the newborn child, already observed in life in the uterus ${ }^{10-11}$. After breastfeeding, the time when babies suck vigorously to extract the milk, both the hunger instinct and sucking instinct are satisfied. If the need to suck is not satisfied during breastfeeding, nonnutritive sucking habits may emerge, such as the use of a pacifier or the sucking of the fingers ${ }^{9-10,12-16}$.

The seriousness of the alterations caused by harmful sucking habits on the dentoalveolar morphology is related to the type, frequency, intensity and duration of the act performed ${ }^{17}$. Alterations may occur to the dental arches and the position of the teeth, as well as problems with joints and changes in the facial and masticatory muscles ${ }^{12,18-20}$

It is essential for the newborn child that maternal breastfeeding is exclusive up to the sixth month of life and is encouraged up until two years of age, seeing that there is a strong correlation between the presence of harmful oral habits and insufficient breastfeeding 1,3-4,17. Swallowing, phonation and breathing may also be affected when the bottle is introduced too early into the baby's routine ${ }^{17}$. From a dental point of view, during correct sucking, the lips and tongue assume a position that is appropriate for working the orofacial muscles, which is important for the correct growth of the mandibular and maxilla, promoting adequate tooth eruption and occlusion 12-13,15.
The physiological need to suck disappears between 9 and 12 months of age, however moments of stress may induce sucking as a way to release tension in the children and bring a sensation of pleasure, wellbeing and safety. The removal of harmful sucking habits is recommended at around three years old, the time when there is a better chance of malocclusions correcting by themselves ${ }^{6,9-10,16,21-22}$. Prolonged periods of non-nutritive sucking may lead to a more severe imbalance in the orofacial structures and these disorders could affect the child's physical, social and psychological wellbeing.

Given the above, the aim of this work was to analyze the relationship between the time of maternal breastfeeding and the emergence of non-nutritive sucking habits in children between 3 and 9 years old, attending the Baby Clinic at the Pediatric Dental Department of the College of Dentistry located on the UNESP campus in Araçatuba, in the state of São Paulo.

\section{METHODS}

To carry out this study, interviews were conducted with the parents or legal guardians of children attending the Baby Clinic at the College of Dentistry on the UNESP campus in Araçatuba. A total of 228 patient records were selected of children between 3 and 9 years of age, of both sexes, who had been breastfed by their mothers.

The interview was carried out with the aim of obtaining the following information: period of natural breastfeeding; presence and duration of non-nutritive sucking habits.

According to the form of lactation, the sample was divided into two groups: group I, comprising children who were exclusively breastfed until 6 months of age; group II, comprising children who were exclusively breastfed for a period longer than 6 months.

The children in each group were classified according to the non-nutritive sucking habits observed: no habit; pacifier and finger; just finger; just pacifier.

In addition to these factors, an evaluation was performed on the prevalence of children receiving mixed feeding, those who were exclusively breastfed or exclusively breastfed with the habit of sucking the fingers.

All parents or patients' legal guardians were informed about the nature and objectives of the study. After carefully reading the consent form and agreeing to the participation of the children in the research study, they signed the free and informed consent form as well as an agreement to carry out the study. 
A descriptive analysis of the results was performed. The variables analyzed were shown by means of frequency and percentage distributions. The data were processed using the application Excel, (Microsoft, Atlanta, GA, USA).

\section{RESULTS}

The sample in the present investigation is made up of 124 females and 104 males, making a grand total of 228 children. Of these, 97 (42.5\%) were breastfed up to 6 months of age, while 131 continued breastfeeding beyond 6 months.

According to Figure 1, considering those children that had non-nutritive sucking habits and were breastfed for a period up to 6 months of age, separated by sex, a total of 53 were female of which $44(83 \%)$ had a nonnutritive sucking habit, such as pacifier and/or fingers while just $9(17 \%)$ of them did not. Of the 44 male children, $32(72.2 \%)$ had a non-nutritive sucking habit and only 12 $(27.3 \%)$ did not. It can be seen from this table that $78.4 \%$ of the children had a non-nutritive sucking habit and only $21.6 \%$ did not have this habit, after being breastfed for a period less than or equal to 6 months.
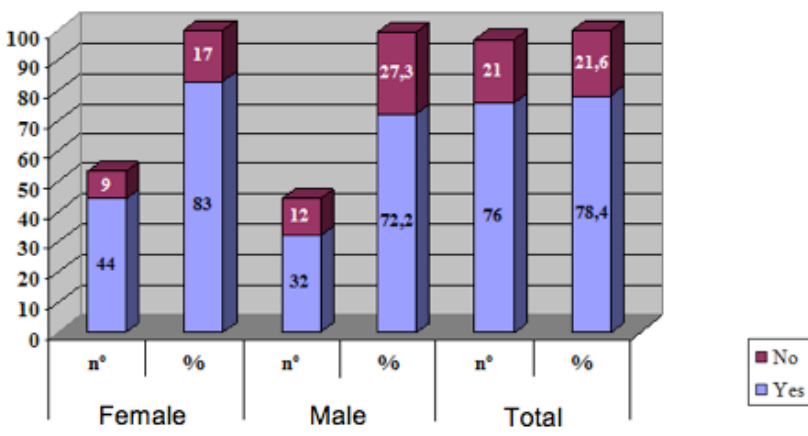

Figure 1. Children that had non-nutritive sucking habits and were breastfed for a period up to six months of age, according to gender.

Figure 2 shows those children who had nonnutritive sucking habits and who were breastfed beyond 6 months. This sample totaled 131 children of which 71 were female and 60 male. Of the females, 26 (36.6\%) had a non-nutritive sucking habit and 45 (63.4\%) did not. As for the male children, 17 (28.3\%) had the habit and 43 $(71.7 \%)$ did not. Therefore a total of $32.8 \%$ of the children had non-nutritive sucking habits as opposed to $67.2 \%$ who did not.

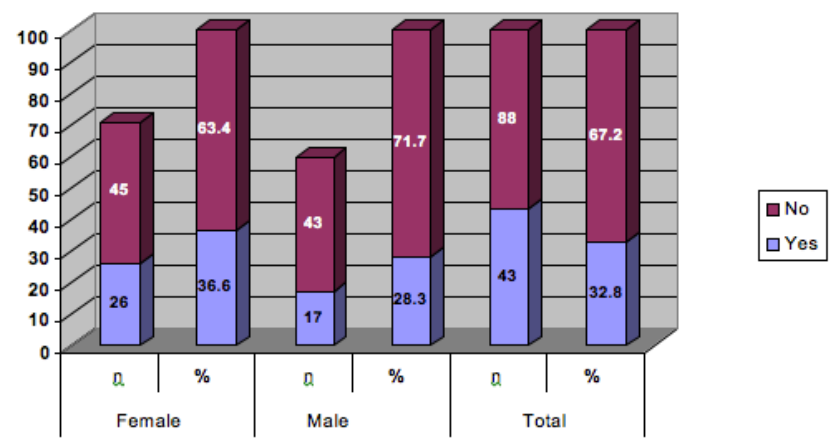

Figure 2. Children that had non-nutritive sucking habits and were breastfed for a period greater than six months of age, according to gender.

According to Figure 3, the incidence of pacifier sucking in children who have received natural breastfeeding up to the age of 6 months was $70.1 \%$, while $21.6 \%$ had no non-nutritive sucking habits. Meanwhile, for children breastfed beyond 6 months of age, the respective numbers were $24.4 \%$ and $67.2 \%$, as demonstrated in Figure 4.

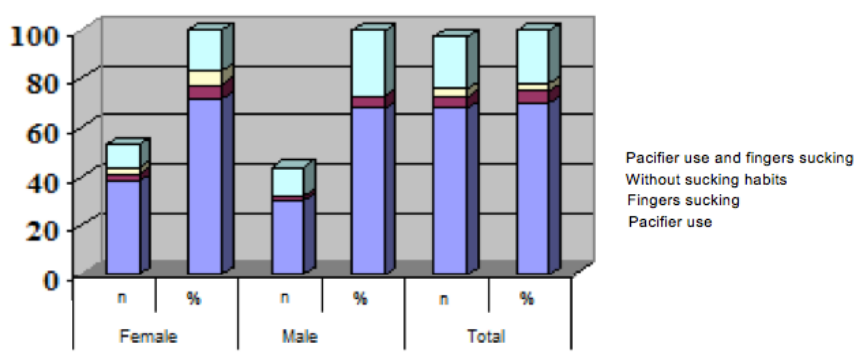

Figure 3. Relationship between non-nutritive sucking habits in children that received maternal breastfeeding up to six months of age.

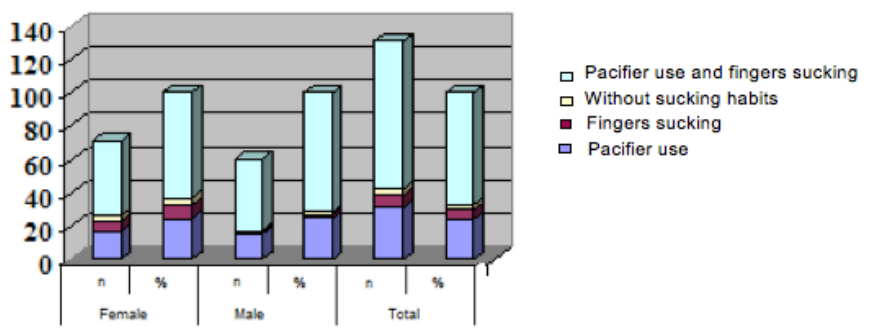

Figure 4. Relationship between non-nutritive sucking habits in children that received maternal breastfeeding for a period greater than six months of age.

The data in table 1 show that all the children who were only breastfed up to a maximum of 6 months, made use of a feeding bottle to complement their nutrition, in other words they had mixed lactation. Meanwhile, of the children who had a longer period of maternal breastfeeding, 17 were exclusively breastfed without any non-nutritive sucking habits. 
Table 1. Prevalence of children who developed non-nutritive sucking habits (habit of sucking the fingers) according to the type/period of lactation.

\begin{tabular}{lcccccc}
\hline & \multicolumn{2}{c}{ Up to $\mathbf{6}$ months } & \multicolumn{2}{c}{$\begin{array}{c}\text { More than } \\
\mathbf{6} \text { months }\end{array}$} & \multicolumn{2}{c}{ Total } \\
\cline { 2 - 7 } & $\mathrm{n}$ & $(\%)$ & $\mathrm{n}$ & $(\%)$ & $\mathrm{n}$ & $(\%)$ \\
\hline Exclusive maternal breastfeeding & 0 & 0 & 17 & 13 & 17 & 7.5 \\
mixed feeding & 97 & 100 & 113 & 86.2 & 210 & 92.1 \\
Total & 97 & 100 & 131 & 100 & 228 & 100 \\
\hline
\end{tabular}

\section{DISCUSSION}

There is a vast amount of literature available that has documented the benefits of exclusive, natural breastfeeding up to 6 months of age. The World Health Organization (WHO) also advocates that maternal breastfeeding should be continued until the child reaches two years of age 1 . This recommendation is extremely important as there is a correlation between the length of breastfeeding and the establishment of non-nutritive sucking habits 8 -10,17,23-24.

The finding that longer periods of natural breastfeeding lead to a lower incidence of harmful oral habits could also be said of the present study, since $67.2 \%$ of the children who continued to be breastfed naturally beyond 6 months were shown not to have non-nutritive sucking habits. In contrast, only $21.6 \%$ of those children having breastfed for only a short period, less than 6 months, were free of this habit. The results of the present study confirm the findings of various investigations, such as those of Miotto et al. ${ }^{4}$, Vasconcelos et al. ${ }^{8}$, Bittencourt et al. ${ }^{14}$, Moimaz et al. ${ }^{17}$, Serra-Negra et al. ${ }^{24}$, Robles et al. ${ }^{25}$ and Praetzel et al. ${ }^{26}$, who also noted a strong link between natural breastfeeding and the absence of harmful oral habits.

With the transition from exclusive breastfeeding to mixed feeding, babies should begin the process of giving up the sucking habit and, at around 24 months, the child no longer has a need for non-nutritive sucking. However the habit could persist for psychological reasons as the sucking of the finger or the pacifier or some other object usually provides the child with a feeling of wellbeing and protection, relieving frustration and stress. When these harmful habits persist for an extended period, there may be adverse consequences for the orofacial structures ${ }^{10,16,19,27-29}$.

According to Pereira ${ }^{22}$, the treatment for the correction of these sequelae is based on the use of orthodontic appliances which generally require lengthy treatment and are not accessible to a large section of the population. Moreover, there may be some difficulty in the acceptance of orthodontic treatments since children do not always have sufficient maturity to cooperate. Thus encouraging natural breastfeeding for longer periods would be a simple form of preventing harmful oral habits and consequently the introduction of orthodontic problems that may require intervention on very young children.

Despite the multiple benefits of maternal breastfeeding, artificial feeding is widely used and contributes to the high rates of pacifier use and other harmful habits. The substitution of mother's milk by a feeding bottle leaves the lactating child unsatisfied as the teat used on the bottle is not adequate and does not stimulate or promote sufficient effort by the baby's orofacial muscles, factors which contribute to premature weaning and the introduction of harmful habits ${ }^{10,17}$.

Many studies have reported a high percentage of artificial lactation, however the results in the literature vary greatly. In a survey conducted by the Ministry of Health in Brazil, it was found that, between 1999 and 2008, there was a significant improvement in the situation visà-vis maternal breastfeeding in the country, however we are still a long way from meeting the targets proposed by the WHO, namely exclusive breastfeeding until the sixth month of life and continuing to breastfeed until the child is at least 2 years old ${ }^{1,3}$. In this survey, it was noted that the median duration of exclusive maternal breastfeeding was 54.1 days (1.8 months) and the median duration of maternal feeding associated with other liquids was 341.6 days (11.2 months) in all of the state capitals and the federal district of Brasilia, combined. For the total number of children analyzed under the age of 12 months, the use of a bottle $(58.4 \%)$ or pacifier $(42.6 \%)$ was frequent.

According to the study by Braghini et al. ${ }^{30}$, exclusive maternal breastfeeding was noted in $71.4 \%$ of the sample, with $38.5 \%$ of these using this form of lactation up to six months, while $32.9 \%$ did so for a period of 3 months. The exclusive use of the feeding bottle from birth was reported in $9.5 \%$ of the questionnaires and mixed lactation in 19\% of the sample. In the present study, it was observed that the median duration of maternal breastfeeding was 8 months. 
This difference may be attributable to the sample size.

Other studies have found similar data, stating that the pacifier is the most harmful oral habit in our culture $10,19,30$. The results of the present investigation confirm the findings of these authors, as shown in graphs 3 and 4 . With regard to harmful oral habits, the incidence of pacifier use in children being breastfed naturally until 6 months of age, was predominant amongst the nonnutritive sucking habits, amounting to $70.1 \%$ of the sample, and $21.6 \%$ did not have any non-nutritive sucking habit. A big difference could be seen when the children were breastfed for a period of time greater than six months, with only $24.4 \%$ using a pacifier, $5.3 \%$ fingers, $3.1 \%$ sucked both fingers and pacifier and $67.2 \%$ had no such harmful habits.

In another study it was observed that, for short breastfeeding periods, the frequency of bottle feeding and harmful habits was high; when maternal breastfeeding continued for between 4 and 8 months, the use of the bottle and the presence of harmful habits declined ${ }^{25}$. As for the studies conducted by Praetzel et al. ${ }^{26}$ and Bayardo et al. ${ }^{2}$, it was ascertained that, when maternal breastfeeding is offered exclusively until 6 months, it is already possible to identify a number of children using pacifiers. Nevertheless, a larger number of children made use of pacifiers when a bottle was offered early on.

In the study by Medeiros and Rodrigues ${ }^{13}, 92 \%$ of children receiving maternal breastfeeding as their only method of feeding in the first six months of life, did not show signs of harmful sucking habits, and in the study carried out by Bittencourt et al. ${ }^{14}$, it was found that natural breastfeeding for a period greater than 12 months contributed to the infrequent use of the pacifier. When the breastfeeding period was six months or less, or between six months and a year, there was 1.2 times higher risk of the use of the pacifier or fingers.

\section{REFERENCES}

1. World Health Organization. Report of the expert consultation on the optimal duration of exclusive breastfeeding: conclusions and recommendations. Geneva; 2001.

2. Bayardo RA, Sanglard-Peixoto LF, Corrêa MSNP. Natural and artificial nursing: general considerations. J Bras Odonto-Psicol Odontol Pacientes Espec. 2003;7(39):257-60.
Similar observations are demonstrated in table 3 , where $13 \%$ of the sample had exclusive maternal breastfeeding and no consequent non-nutritive sucking habits. Only one child had the habit of sucking its fingers after having been exclusively breastfed. This outcome was only observed for those children who were breastfed by their mothers for more than 6 months, where 86.2\% received mixed feeding, while in those that have been breastfed for a short period, they did not have exclusive lactation, being mixed in $100 \%$ of cases.

Given the above, it is important that professionals provide guidance to their patients in terms of non-nutritive sucking habits, so that they do not turn into factors that trigger alterations in the development and growth of the structures which comprise the stomatognathic system. It is clear that the Pediatric Dentist, as a health professional, should be capable of educating the mothers as to the importance of exclusive, maternal breastfeeding up to six months of age in order to benefit the development of the new-born child's health.

\section{CONCLUSION}

Based on the results obtained in this study, it can be concluded that the period of maternal breastfeeding was associated with the acquisition of non-nutritive sucking habits and that there was a larger number of children who developed non-nutritive sucking habits when breastfed for less than 6 months.

In addition, the prevalence of harmful sucking habits was high, the habit of sucking the pacifier being the most prevalent in the group of children who only had maternal breastmilk in the first six months of life. In the group of children that received maternal breastfeeding for a period greater than six months, the incidence of the pacifier habit was lower.

3. Brasil. Ministério da Saúde. II Pesquisa de Prevalência de Aleitamento Materno nas Capitais Brasileiras e Distrito Federal [ciado 2014 Set 10]. Disponível em: <http://www.redeblh. fiocruz.br/media/pamuni.pdf>

4. Miotto MHMB, Caxias FPC, Campos DMKS, Ferreira LFPEF, Barcellos, LAB. Aleitamento materno como fator de proteção contra a instalação de hábitos bucais deletérios. Rev CEFAC. 2014;16(1):244-51. 
5. Baldrighi SEZM, Pinzan A, Zwicker CVD, Michelini CRS, Barros $D R$, Elias F. The importance of the natural milk to prevent myofunctonal and orthodontics alterations. Dental Press Ortodon Ortop Facial. 2001;6(5):111-21.

6. Martins RJ, Forte FDS, Garbin CAS, Moimaz SAS, Saliba NA. Relação entre hábitos de sucção não nutritiva e mordida aberta anterior. Rev Inst Cienc Saúde. 2003;21(4):401-4.

7. Coeli BM, Toledo OA. Suctions buccal habits: aspects related with the etiology and treatment. Rev Odontopediatria. 1994;3(1):43-51.

8. Vasconcelos FMN, Massoni ACLT, Heimer MV, Ferreira AMB, Katz CRT, Rosenblat A. Non-nutritive sucking habits, anterior open bite and associated factors in Brazilian children aged 30-59 months. Braz Dent J. 2011;22(2):140-5. doi: 10.1590/S010364402011000200009

9. Zuanon ACC, Nogueira IO, Ricci H, Ferrari JCL. Sucção: importância e prejuízo. RCO: UniEvangélica. 2008;10(2):59-61.

10. Góes MPS, Araujo CMT, Góes OS, Jamelli SR. Persistência de hábitos de sucção não nutritiva: prevalência e fatores associados. Rev Bras Saúde Matern Infant. 2013;13(3):247-57.

11. Douglas CR. Suction physiology. In: Douglas CR. Patofisiologia oral: fisiologia normal e patológica aplicada à odontologia e fonoaudiologia. São Paulo: Pancast; 1998. p. 237-43.

12. Palumbo A, Queluz DP. Avaliação de escolares: amamentados no peito e/ou na mamadeira em relação ao trespasse horizontal. J Bras Odontopediatra Odontol Bebê. 1999;2(5):42-8.

13. Medeiros EB, Rodrigues MJ. A importânica da amamentação natural para o desenvolvimento do sistema estomatognático do bebê. Rev Cons Reg Odontol Pernambuco. 2001;4 (2):79-83.

14. Bittencourt LP, Modesto A, Bastos EPS. Influência do aleitamento sobre a freqüência dos hábitos de sucção. Rev Bras Odontol. 2001;58(3):191-3

15. Lopes GM, Oliveira LB. Prevenção da maloclusão pela amamentação. In: Pedrosa SF, Moysés SJ, Groisman S. (Org.). Pro-Odonto prevenção: Programa de atualização em odontologia Preventiva e saúde coletiva. 4[ ed. Porto Alegre: Artmed Panamericana; 2010. p. 81-142.

16. Rottman RW, Imparato JCP, Ortega AOL. Apresentação de método motivacional para remoção de hábito de sucção não nutritiva. Revisão de literatura e relato de caso. J Biod Biomat. 2011;1:49-60.

17. Moimaz SAS, Rocha NB, Garbin AJl, Saliba O. A influência da prática do aleitamento materno na aquisição de hábitos de sucção não nutritivos e prevenção de oclusopatias. Rev Odontol UNESP. 2013;42(1):31-6.
18. Rabello MCVB, Baussels J, Benfatti SV, Percinoto C. Hábitos de sucção em crianças do município de Marilia, SP. Rev Ciências Odontológicas. 2000;3(3):59-65.

19. Bishara SE, Warren JJ, Broffitt B, Levy SM. Changes in the prevalence of nonnutritive sucking patterns in the first 8 years of life. Am J Orthod Dentofacial Orthop. 2006;130(1):31- 6.

20. Boeck EM, Pizzola KEC, Barbosa EGP, Pires CA, Lunardi N. Prevalência de má oclusão em crianças de 3 a 6 anos portadoras de hábito de sucção de dedo e/ou chupeta. Rev Odontol UNESP. 2013;42(2):110-6.

21. Zuanon ACC, Oliveira MF, Giro EMA, Maia JP. Influência da amamentação natural e artificial no desenvolvimento dos hábitos bucais. J Bras Odontopediatr Odontol Bebê. 1999;2(8):303-6.

22. Pereira VP, Schardosim LR, Costa CT. Remoção do hábito de sucção de chupeta em pré-escolares: apresentação e avaliação de uma estratégia motivacional. Rev Fac Odontol Porto Alegre. 2009;50(3):27-31

23. Ferreira MIDT, Toledo AO. Relação entre tempo de aleitamento materno e hábitos bucais. Rev ABO Nac. 1997;5(5):317-20.

24. Serra-Negra JMC, Pordeus IA, Rocha Júnior JF. Estudo da associação entre aleitamento, hábitos bucais e mau oclusões. Rev Odontol Univ São Paulo. 1997;11(2):79-86.

25. Robles FRP, Mendes FM, Haddad AE, Corrêa MSNP. A influência do período de amamentação nos hábitos de sucção persistentes e a ocorrência de más oclusões em crianças com dentição decídua completa. Rev Paul Odontol.1999;21(3):4-9.

26. Praetzel JR, Saldanha MJQ, Pereira JES, Guimarães MB. Breast and bottle-feeding $X$ pacifiers. J Bras Odontopediatr Odontol Bebe. 2002; 5(25):235-40.

27. Barretto EPR Faria MMG, Castro PRS. Non-nutritive sucking habits: multidisciplinary approach. J Bras Odontopediatr Odontol Bebe. 2003;6(29):42-8.

28. Mistry P, Moles DR, O'Neill J, Noar J. The occlusal effects of digit sucking habits amongst school children in Northamptonshire (UK). J Orthod. 2010;37(2):87-92. doi: 10.1179/14653121042939.

29. Turgeon-O'Brien HT, Lachapelle D, Gagnon PF, Larocque I, Maheu-Robert, LFM. Nutritive and nonnutritive sucking habits: a review. ASDC J Dent Child. 1996;63(5):321-7.

30. Braghini M, Dolci GS, Ferreira EJB, Drehmer TM. Relação entre aleitamento materno, hábito de sucção, forma do arco e profundidade do palato. Ortodon gaúch. 2002;6(1):57-64.

Received on: 13/11/2014 Final version resubmitted on: 23/1/2015 Approved on: 17/2/2015 